\title{
On secondary new particle formation in China
}

\section{Kulmala, Markku}

2016-10

Kulmala , M , Petaja , T , Kerminen , V-M , Kujansuu, J , Ruuskanen , T , Ding , A , Nie , W , Hu , M , Wang , Z, Wu , Z, Wang , L \& Worsnop, D R 2016 , ' On secondary new particle formation in China ', Frontiers of Environmental Science \& Engineering in China, vol. 10 , no. 5 , 08 . https://doi.org/10.1007/s11783-016-0850-1

http://hdl.handle.net/10138/224159

https://doi.org/10.1007/s11783-016-0850-1

other

acceptedVersion

Downloaded from Helda, University of Helsinki institutional repository.

This is an electronic reprint of the original article.

This reprint may differ from the original in pagination and typographic detail.

Please cite the original version. 


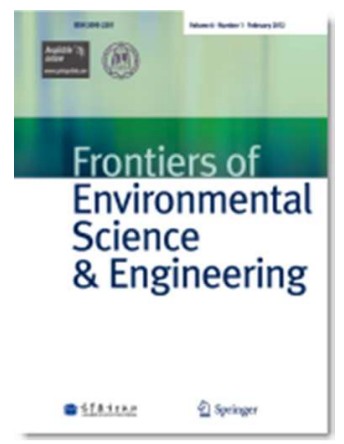

\section{On secondary new particle formation in China}

\begin{tabular}{|c|c|}
\hline Journal: & Frontiers of Environmental Science and Engineering \\
\hline Manuscript ID & FESE-2016-0074.R1 \\
\hline Manuscript Type: & Special Issue: Progresses in understanding secondary air pollution \\
\hline Date Submitted by the Author: & $\mathrm{n} / \mathrm{a}$ \\
\hline Complete List of Authors: & $\begin{array}{l}\text { Kulmala, Markku; University of Helsinki } \\
\text { Petäjä, Tuukka; University of Helsinki; Nanjing University and University of } \\
\text { Helsinki } \\
\text { Kerminen, Veli-Matti; University of Helsinki } \\
\text { Kujansuu, Joni; University of Helsinki } \\
\text { Ruuskanen, Taina; University of Helsinki } \\
\text { Ding, Aijun; Institute for Climate and Global Change Research; Nanjing } \\
\text { University and University of Helsinki } \\
\text { Nie, Wei; University of Helsinki; Nanjing University and University of } \\
\text { Helsinki ; Institute for Climate and Global Change Research } \\
\text { HU, Min; State Key Joint Laboratory of Environmental Simulation and } \\
\text { Pollution Control, College of Environmental Sciences and Engineering } \\
\text { Wang, Zhibin; Max Planck Institute for Chemistry; State Key Joint } \\
\text { Laboratory of Environmental Simulation and Pollution Control, College of } \\
\text { Environmental Sciences and Engineering } \\
\text { Wu, Zhijun; State Key Joint Laboratory of Environmental Simulation and } \\
\text { Pollution Control, College of Environmental Sciences and Engineering } \\
\text { Wang, Lin; Fudan University, } \\
\text { Worsnop, Douglas; University of Helsinki; Aerodyne Research Inc }\end{array}$ \\
\hline Keywords: & $\begin{array}{l}\text { aerosol particles, heavily-polluted environments, condensation sink, new } \\
\text { particle production, megacities }\end{array}$ \\
\hline Speciality: & $\begin{array}{l}\text { Formation < POLLUTION, Particle-phase species < POLLUTION, Mass } \\
\text { spectrometry < ANALYTICAL METHODS }\end{array}$ \\
\hline
\end{tabular}




\section{Page 1 of 43}

FESE

1

2

3
4

4

5

6
7

8

9

10

11

12

13

14

15

16

17

18

19

20

21

22

23

24

25

26

27

29

30

31

32

33

34

35

36

37

38

39

40

41

42

43

44

45

46

47

48

49

50

51

52

53

54

55

56

57

58

59

60

https://mc.manuscriptcentral.com/fese 
1 The original question from guest editor: your view or comments or directions

2 related to secondary aerosol formation in China

3

4 Journal: Front. Environ. Sci. Eng

5

6 Title:

7 On secondary new particle formation in China

8

9 Running title:

10 On secondary new particle formation in China

11

12 Correspondence author

13 Markku Kulmala

14 University of Helsinki

15 P.O. Box 64

16 Helsinki, FI 00014, Finland

17 markku.kulmala@helsinki.fi

18 Tel: +358-40-5962311 
19 Fax: +358-9-19150717

20

21 Markku Kulmala ${ }^{1}$

$22 \quad{ }^{1}$ University of Helsinki

23 P.O. Box 64

24 Helsinki, FI 00014, Finland

25 markku.kulmala@helsinki.fi

26

27 Tuukka Petäjä ${ }^{1,2}$

$28{ }^{1}$ University of Helsinki

29 P.O. Box 64

30 Helsinki, FI 00014, Finland

31 tuukka.petaja@helsinki.fi

$32{ }^{2}$ Joint International Research Laboratory of Atmospheric and Earth System Sciences

33 (JirLATEST)

34 Nanjing University and University of Helsinki

3522 Hankou Road, Nanjing, CN 210093, China

36

37 Veli-Matti Kerminen ${ }^{1}$ 
$38 \quad{ }^{1}$ University of Helsinki

39 P.O. Box 64

40 Helsinki, FI 00014, Finland

41 veli-matti.kerminen@helsinki.fi

42

43 Joni Kujansuu $^{1}$

$44 \quad{ }^{1}$ University of Helsinki

45 P.O. Box 64

46 Helsinki, FI 00014, Finland

47 joni.kujansuu@helsinki.fi

48

49 Taina Ruuskanen ${ }^{1}$

$50 \quad{ }^{1}$ University of Helsinki

51 P.O. Box 64

52 Helsinki, FI 00014, Finland

53 taina.ruuskanen@helsinki.fi

54

55 Aijun Ding ${ }^{2,3}$ 
1

2

3

4

5

6

7

8

9

10

11

12

13

14

15

16

17

18

19

20

21

22

23

24

25

26

27

28

29

30

31

32

33

34

35

36

37

38

39

40

41

42

43

44

45

46

47

48

49

50

51

52

53

54

55

56

57

58

59

60

$56{ }^{2}$ Joint International Research Laboratory of Atmospheric and Earth System Sciences

57 (JirLATEST)

58 Nanjing University and University of Helsinki

5922 Hankou Road, Nanjing, CN 210093, China

$60 \quad{ }^{3}$ Institute for Climate and Global Change Research

61 Nanjing University

62 Nanjing, Jiangsu, CN 210000, China

63 dingaj@nju.edu.cn

64

65 Wei Nie ${ }^{1,2,3}$

$66{ }^{1}$ University of Helsinki

67 P.O. Box 64

68 Helsinki, FI 00014, Finland

$69{ }^{2}$ Joint International Research Laboratory of Atmospheric and Earth System Sciences

70 (JirLATEST)

71 Nanjing University and University of Helsinki

722 Hankou Road, Nanjing, CN 210093, China

$73{ }^{3}$ Institute for Climate and Global Change Research

74 Nanjing University 
75 Nanjing, Jiangsu, CN 210000, China

76 niewei@nju.edu.cn

77

$78 \mathrm{Min} \mathrm{Hu}^{4}$

$79{ }^{4}$ State Key Joint Laboratory of Environmental Simulation and Pollution Control,

80 College of Environmental Sciences and Engineering, Peking University

81 Beijing, CN 100871, China

82 minhu@pku.edu.cn

83

84 Zhibin Wang ${ }^{4,5}$

$85{ }^{4}$ State Key Joint Laboratory of Environmental Simulation and Pollution Control,

86 College of Environmental Sciences and Engineering, Peking University

87 Beijing, CN 100871, China

$88 \quad{ }^{5}$ Max Planck Institute for Chemistry

89 Hahn-Meitner-Weg 1, Mainz, DE 55128, Germany

90 zhibin.wang@mpic.de

91

92 Zhijun $\mathrm{Wu}^{4}$ 
1

2

3

4

5

6

7

8

9

10

11

12

13

14

15

16

17

18

19

20

21

22

23

24

25

26

27

28

29

30

31

32

33

34

35

36

37

38

39

40

41

42

43

44

45

46

47

48

49

50

51

52

53

54

55

56

57

58

59

60
$93{ }^{4}$ State Key Joint Laboratory of Environmental Simulation and Pollution Control,

94 College of Environmental Sciences and Engineering, Peking University

95 Beijing, CN 100871, China

96 zhijunwu@pku.edu.cn

97

98 Lin Wang ${ }^{6}$

$99{ }^{6}$ Fudan University, Department of Environmental Science \& Engineering

100 Shanghai, CN 200433, China

101 lin_wang@fudan.edu.cn

102

103 Douglas R. Worsnop ${ }^{1,7}$

$104{ }^{1}$ University of Helsinki

105 P.O. Box 64

106 Helsinki, FI 00014, Finland

$107{ }^{7}$ Aerodyne Research Inc

108 Billerica, MA, USA 01821

109 worsnop@aerodyne.com

110

111 Abstract 
113 Formation of new atmospheric aerosol particles is a global phenomenon that has been

114 observed to take place in even heavily-polluted environments. However, in all

115 environments there appears to be a threshold value of the condensation sink (due to

116 pre-existing aerosol particles) after which the formation rate of $3 \mathrm{~nm}$ particles is no

117 longer detected. In China, new particle production has been observed at very high

118 pollution levels (condensation sink about $0.1 \mathrm{~s}^{-1}$ ) in several megacities, including

119 Beijing, Shanghai and Nanjing as well as in Pearl River Delta (PRD). Here we

120 summarize the recent findings obtained from these studies and discuss the various

121 implications these findings will have on future research and policy.

122

123

124

125

126 all, the interaction between aerosols and climate system is the dominant uncertainty in

127 predicting the radiative forcing and future climate [1]. Secondly, aerosol particles

128 deteriorate both human health and visibility, especially in urban areas $[2,3]$. Thirdly,

129 aerosol particles modify the intensity and distribution of radiation that reaches the

130 Earth's surface, having direct influences on photosynthesis and terrestrial carbon sink

131 [4]. Better understanding of the various effects in the atmosphere requires detailed

132 information on how different sources (including those related to the biosphere) and

133 atmospheric transformation processes modify the properties of aerosol particle

134 populations. 
136 One of the most important phenomena associated with the atmospheric aerosol

137 number concentrations is the secondary formation of new aerosol particles. This

138 includes the production of molecular clusters from gaseous precursor vapors, the

139 activation and growth of some of these clusters to detectable sizes, and the further

140 growth up to the sizes at which the particles may act as cloud condensation nuclei

141 [e.g. 5, 6]. Although atmospheric new particle formation has been observed to take

142 place almost everywhere at favorable conditions in the boundary layer [7], our

143 knowledge about this phenomenon is still far from perfect $[5,8]$. The current

144 knowledge gaps in this regard range from the basic process-level understanding of

145 secondary atmospheric aerosol formation to its connection with anthropogenic

146 activities, biogenic emissions, atmospheric chemistry, and ultimately with climate

147 change and human health.

148

149 Secondary formation of new atmospheric aerosol particles is typically initiated by

150 photochemical reactions in the gas phase, so that especially the production of

151 extremely low volatility vapors like sulfuric acid $[9,10,11]$ and highly-oxidized

152 organic compounds [e.g. $12,13,14]$ is crucial. Pre-existing aerosol particles act as a

153 sink for the low-volatile vapors, as well as for small clusters and growing

154 nanoparticles, thereby hindering or even suppressing atmospheric new particle

155 formation [e.g. 15, 16, 17]. The atmospheric new particle formation is affected by

156 several meteorological quantities and phenomena, particularly in the planetary

157 boundary layer, including the intensity of solar radiation and atmospheric mixing 
158 processes. The recent findings indicate that critical clusters may be surprisingly small

159 in size, if existing at all, under atmospheric conditions [e.g. 18], and thus treatable by

160 advanced quantum chemistry methods [19]. It is very probable that the atmospheric

161 new particle formation is a two-step process, i.e. initial clustering and then

162 condensational growth after activation of clusters, as suggested by Kulmala et al. [21]

163 and verified by Kulmala et al. [18]. A summary of the current understanding of gas-

164 to-particle conversion is presented by Kulmala et al. [5].

165 New aerosol particles formed in the atmosphere become climatically important when

166 they reach sizes larger than about $50-100 \mathrm{~nm}$ in diameter [6]. Particles of this size

167 and larger are able to act as cloud condensation nuclei and scatter visible light,

168 thereby affecting cloud microphysical properties [e.g. 22], reducing the fraction of

169 solar radiation reaching the Earth's surface and contributing to visibility degradation

170 [e.g. 23]. Furthermore, health effects of airborne particles are related not only to the

171 amount and toxicity of the particulate material, but also to the particle size because

172 this property has a large effect on whether or not a particle is able to penetrate into the

173 lungs [e.g. 20] and even further into the blood circulation [e.g. 24].

174

175 The rapid, large-scale urbanization and industrialization of China are unique in 176 history. Consequently, China's air pollution situation has worsened dramatically

177 during the last 2-3 decades as emissions from industry, energy production and traffic

178 have increased. China is currently responsible for $30-35 \%$ of the global $\mathrm{SO}_{2}, \mathrm{NO}_{\mathrm{x}}$,

$179 \mathrm{CO}$ and Particulate mass (PM) emissions and 40\% of global particle number (PN)

180 emission in the 20-1000 nm size range (see http://gains.iiasa.ac.at/gains3/). 
181 Atmospheric concentrations of primary and secondary pollutants in China are 10 to

182100 times (sometimes even 1000 times) higher than currently in Europe or Northern

183 America. However, highly non-linear processes, such as atmospheric chemistry and

184 aerosol dynamics, transform the urban pollution cocktail and generate secondary

185 pollution, such as ultrafine particles and ozone, during their residence in the

186 atmosphere $[25,26]$. The fact that new particle formation does occur in polluted

187 Chinese megacities like Beijing [27] and Shanghai [28], or even during dust-storms

$188[29,30]$, suggests that there are several major physical and chemical mechanisms in a

189 heavily-polluted atmosphere that have not been recognized before and may not even

190 be operating in clean or moderately-polluted environments. At present, atmospheric

191 air pollution in China threatens the health of hundreds of millions of people [e.g. 3,

192 31], and causes major problems to the environment and economy as a whole by

193 decreasing, e.g. severely the agricultural and industrial productivity of the nation as a

194 whole. This pollution also reduces visibility, thereby decreasing the attraction of these

195 mega-cities for tourists, and hinders the possibilities to use solar energy a source for a

196 clean energy on a local scale.

197

198 A holistic scientific understanding on the atmospheric phenomena associated with air

199 quality as a whole, as well as on the connection between air quality and climate, is

200 lacking at the moment [31-33]. Together with emission reductions, the key way to get

201 forward is to perform long-term, continuous and comprehensive observations on

202 aerosol particles (mass, number, chemical composition, optical properties), on

203 concentrations of trace gases $\left(\mathrm{SO}_{2}, \mathrm{NO}_{\mathrm{x}}, \mathrm{CO}\right.$, VOCs, sulphuric acid, $\mathrm{HONO}, \mathrm{HNO}_{3}$,

$204 \mathrm{NH}_{3}$ etc. $)$, and on atmospheric oxidant levels $\left(\mathrm{O}_{3}, \mathrm{HO}_{\mathrm{x}}, \mathrm{RO}_{\mathrm{x}}, \mathrm{NO}_{3}\right.$, Criegee 
205 intermediates etc.), as well as on greenhouse gas concentrations [31]. With a network 206 of such observation stations [34], we will be able to understand the interactions and 207 feedbacks associated with the urban pollution mixture [e.g. 35-37], and ultimately, be 208 ready to make targeted strategies for the pollution control. In the following we take 209 recent advances in studying secondary new aerosol formation in China as an example 210 to show how increased process-level understanding will help us to understand air 211 quality-climate-weather interactions and how the feedbacks and interactions affect the 212 air quality in highly-polluted environments such as those frequently encountered in 213 Chinese megacities.

\section{2. Results from recent studies on New Particle Formation in China}

217 New particle formation events have been observed in many different locations in 218 China, including coastal/marine, rural, regional and polluted urban environments [28, $21930,38-47]$.

221 The first long-term study on NPF events was performed in the urban of Beijing at 222 PKU Urban Atmosphere Environment MonitoRing Station (PKUERS), starting at $2232004[27,48,49]$. On average, every fifth day ( 21\%) displayed a NPF event [50]. An 224 evident seasonal variation profile for NPF events was observed, showing that a high 225 frequency the NPF events $(\sim 40 \%)$ occurred during the spring and winter $[27,50]$, 226 while fewer events were observed in summer [51, 52]. The observed formation rates 
227 of 3-nm particles and their growth rates were in the ranges of $3.3-81.4 \mathrm{~cm}^{-3} \mathrm{~s}^{-1}$ and $228 \quad 0.1-11.2 \mathrm{~nm} \mathrm{~h}^{-1}[27,50,53]$, respectively.

230 Generally, NPF is an unexpected phenomenon in the polluted atmosphere of China 231 due to typically high loadings of pre-existing aerosol particles. For example, the mean 232 condensation sink (CS, [54]) values during the nucleation event days were $0.025 \mathrm{~s}^{-1}$ $233\left(0.003-0.086 \mathrm{~s}^{-1}\right)$ and $0.026 \mathrm{~s}^{-1}\left(0.004-0.082 \mathrm{~s}^{-1}\right)$ at the rural (Kaiping) and urban 234 (Beijing) environments, respectively, which are approximately 5 to 10 times higher 235 than the values of CS observed in clean environments [55-57]. This high 236 concentration of pre-existing aerosol particles significantly inhibits the growth of 237 newly-formed particles. In fact, the observed NPF event is an end product of the 238 competition between the low-volatile vapor sources (such as $\mathrm{SO}_{2}$ or sulfuric acid) and 239 sinks (such as pre-existing particles), as shown by Kulmala et al. [55]. The abundant $240 \mathrm{SO}_{2}$ emissions and high oxidation capacity in the polluted atmosphere of China 241 indicate that there is a sufficient source of sulfuric acid [40, 52]. Therefore, in the case 242 of both higher source and sink, their inter-competition is the most likely factor that 243 determines the occurrences of NPF events in polluted environments.

245 Two years (2011-2013) of continuous particle number size distribution measurements 246 were conducted at the Station for Observing Regional Processes of the Earth System 247 (SORPES $[35,36]$ ) station about $20 \mathrm{~km}$ northeast of urban Nanjing. The location can 248 be considered as a regional background site of Yangtze River Delta in eastern China. 249 During this time period, $44 \%$ of the sampling days were NPF event days (see Figure 1 
250 as an example). The formation rates of 6-nm particles varied from 0.24 to $10.9 \mathrm{~cm}^{-3} \mathrm{~s}^{-}$

$251{ }^{1}$, the subsequent particle growth rates varied from 3.6 to $23 \mathrm{~nm} \mathrm{~h}^{-1}$, and the values of

252 CS during the event days varied from 0.007 to $0.068 \mathrm{~s}^{-1}$ [47]. Most of the NPF events

253 took place in spring, summer and autumn with the frequencies of 55,54 and $49 \%$,

254 respectively, whereas only 15 events $(11.2 \%)$ were observed in winter.

255

256 Figure 1. A typical nucleation event measured using Air Ion Spectrometer (AIS) at 257 the SORPES station, Nanjing, in China. The background cluster ions are seen in both 258 negative and positive ion modes in the sub-2 $\mathrm{nm}$ size range. Negative ion clusters are 259 smaller than positive ones. The new particle formation is seen in both polarities 260 starting at around $8.30 \mathrm{am}$. Here $\mathrm{J}_{6}$ is $1.8 \mathrm{~cm}^{-3} \mathrm{~s}^{-1}$ and GR $(6-30 \mathrm{~nm})$ is $6.6 \mathrm{~nm} \mathrm{~h}^{-1}$.

262 The typical NPF event in Nanjing is shown in Figure 1. In Nanjing, many of the NPF 263 events occurred on the days associated with heavy pollution. As shown by Xie et al. 264 [30], frequent NPF events were observed when the $\mathrm{PM}_{2.5}$ and $\mathrm{PM}_{10}$ concentrations 265 were in excess of $100 \mu \mathrm{g} \mathrm{m}^{-3}$ and $200 \mu \mathrm{g} \mathrm{m}^{-3}$, respectively. The reason for this is still 266 an open question. One hypothesis is that nucleation can be promoted by 267 heterogeneous reactions on the surface of the dust $[29,30]$. This is supported by many 268 observations from both SORPES station and another mountain top site, Mt. Heng in 269 southern China. In the spring of 2009 , relatively high new-particle formation rates $270\left(0.46 \mathrm{~cm}^{-3} \mathrm{~s}^{-1}\right)$ and growth rates $\left(7.2 \mathrm{~nm} \mathrm{~h}^{-1}\right)$ were observed when the loading of pre271 exist particles was higher than $600 \mu \mathrm{g} \mathrm{m} \mathrm{m}^{-3}$ at Mt. Heng. Combined with laboratory 
272 investigations [58], dust-induced heterogeneous photochemical processes were

273 supposed to provide additional gaseous oxidants to promote the NPF [29].

274

275 In urban Shanghai, particle size distributions were measured from November 2013 to 276 January 2014 on the rooftop of a teaching building $\left(31^{\circ} 18^{\prime} \mathrm{N}, 121^{\circ} 30^{\prime} \mathrm{E}\right)$ on the 277 campus of Fudan University [28], which can be regarded as an urban site. During this 278 62-day campaign, 13 NPF events were identified with strong bursts of sub-3 nm 279 particles and subsequent fast growth of these particles. The observed nucleation rate 280 ( $\left.J_{1.34}\right)$, formation rate of $3 \mathrm{~nm}$ particles $\left(J_{3}\right)$, and CS were in the ranges of 112.4$281271.0 \mathrm{~cm}^{-3} \mathrm{~s}^{-1}, 2.3-19.2 \mathrm{~cm}^{-3} \mathrm{~s}^{-1}$ and $0.030-0.10 \mathrm{~s}^{-1}$, respectively. The growth rages of 282 the formed clusters and nanoparticle showed a clear size dependence, with average 283 values of $\mathrm{GR}_{1.35 \sim 1.39}, \mathrm{GR}_{1.39 \sim 1.46}, \mathrm{GR}_{1.46 \sim 1.70}, \mathrm{GR}_{1.70 \sim 2.39}, \mathrm{GR}_{2.39 \sim 7}$ and $284 \mathrm{GR}_{7 \sim 20}$ being $1.6 \pm 1.0,1.4 \pm 2.2,7.2 \pm 7.1,9.0 \pm 11.4,10.9 \pm 9.8$ and $11.4 \pm 9.7 \mathrm{~nm} \mathrm{~h}^{-1}$ 285 respectively. Nucleation of particles during this campaign might be explained by the 286 activation theory, since the formation rate of the smallest particles was proportional to 287 a $0.65 \pm 0.28$ power of the sulfuric acid proxy. In addition, ammonia was very likely 288 associated with NPF events, as the new particle formation rate was positively 289 correlated with the concentration of gas-phase ammonia. The estimated sulfuric acid 290 concentration was sufficient to explain the growth of $1.34-3 \mathrm{~nm}$ particles, but its 291 contribution became smaller as the particle grew in size. 
293 The observed new particle rates, condensation sink and particle growth rates in the 294 three megacities, i.e. Beijing, Nanjing and Shanghai, are of the same order of 295 magnitude. These similarities reflect the urban nature of the Beijing and Shanghai 296 sites, and hint that the Nanjing site, although considered as a regional background site 297 of Yangtze River Delta in eastern China, might be characterized with a similar 298 competition between the sources and sinks of low-volatility vapors. The seasonal 299 pattern of the NPF frequency is very different between the two sites having long-term 300 measurements, Beijing and Nanjing, in addition which the annual-averaged NPF 301 frequency is clearly higher in Nanjing. The fundamental reason for these differences 302 lies probably in a delicate balance between the factors that favor or suppress new 303 particle formation and growth. At both Beijing and Nanjing, for example, NPF is 304 favored by a low ambient relative humidity and low CS, whereas no consistent pattern 305 can be seen between the occurrence of NPF and either the ambient temperature or 306 sulfur dioxide concentration $[27,47]$. The fact that high values of CS tend to suppress 307 NPF is fully in line with theoretical expectations $[16,17]$, and it might explain the low 308 NPF frequency observed in Shanghai during polluted winter conditions [28]. There is 309 strong, yet indirect evidence that NPF events in these three megacities are connected 310 to sulfuric acid $[28,29,40,52]$. However, it is premature to conclude that the exact 311 nucleation mechanisms are identical in three megacities without direct measurements 312 of chemical composition of nucleating clusters and ions.

314 Besides the direct connection between pre-exist aerosols (e.g. mixed dust) and NPF, a 315 recent study found that biomass burning particles can enhance the conversion rate of 
$316 \mathrm{NO}_{2}$ to $\mathrm{HONO}$ which is one of the main sources of $\mathrm{OH}$ and can in turn promote the

317 formation of secondary aerosol mass and number [59]. Furthermore, it was found that

318 when biomass burning particles are mixed with anthropogenic pollution, the HONO

319 production potential from the conversion of $\mathrm{NO}_{2}$ to $\mathrm{HONO}$ tend to be enhanced even

320 more. Given that biomass burning particles are easily mixed with anthropogenic

321 pollution in eastern China, their influences on the HONO budget, radical pool, and

322 thus the formation of secondary aerosols are expected to be important [59].

324 Heterogeneous, or multi-phase, processes influence the secondary aerosol formation.

325 For example, most of aerosol sulfate has been believed to be formed from 326 heterogeneous or aqueous-phase processes (cloud processes). Ozone and hydrogen 327 peroxide are the major oxidants to drive these processes. Recent studies have shown 328 that $\mathrm{NO}_{2}$ can also be an important oxidant to convert $\mathrm{SO}_{2}$ to sulfate when mineral dust 329 and biomass burning plumes are present $[30,60]$. Especially during the biomass 330 burning-induced haze events [30], the oxidation processes by $\mathrm{NO}_{2}$ became critical 331 when the formation of other oxidants were suppressed. More interestingly, one of the 332 "by-products" of the reaction of $\mathrm{SO}_{2}$ and $\mathrm{NO}_{2}$ is $\mathrm{HONO}$, which can further enhance 333 the atmospheric oxidation capacity. All these observations suggest that our current 334 understanding on secondary aerosol formation processes need to be revised. 
338 The importance of secondary aerosols has become apparent during the last decades, 339 so there is an increasing need for understanding their formation mechanisms and 340 atmospheric dynamics in detail. Although several field campaigns and a few long341 term (over several years) observations on NPF have already been conducted in China, 342 we need to perform additional long-term measurements, preferable continuous and 343 comprehensive observations utilizing the full capacity of the current state-of-the-art 344 instruments.

346 In the coming decade, we need to utilize the full capacity of new aerosol and ion 347 instruments, such as the Particle Size Magnifier (PSM, [61]), Neutral cluster and Air 348 Ion Spectrometer (NAIS, [62]) and Sigma [63]. With these instruments, we will be 349 able to detect and analyze the frequency of NPF events, as well as to determine cluster 350 concentrations, particle formation rates and size-dependent particle growth rates [e.g. $35164,65]$. Furthermore, we will be able to quantify the contribution of ion and neutral 352 pathways to NPF $[66,67]$.

354 The aerosol and ion instruments together with the high-resolution mass spectrometers, 355 such as Atmosperic Pressure interface - Time of Flight mass spectrometer (APiTOF, 356 [68] and Chemical Ionization APiTOF [69], will make it possible to connect the NPF 357 to the concentrations of different vapors participating in this process. Such vapors 358 include sulfuric acid [9, 70, 71], ammonia [72], amines [12, 73] and organic vapors $359[11,13,74]$. Furthermore, the mass spectrometers can also be utilized in determining 
1

2

3

4

5

6

7

8

9

10

360 atmospheric radical concentrations [75, 76, 77] responsible for the oxidation of

361 precursor vapors in the atmosphere.

362

363 To support the NPF analysis, aerosol number size distributions need to be measured

364 with harmonized instruments [78], enabling quantification of the condensation sink of 365 a pre-existing particle population. On-line chemical analysis is important as well, 366 since such information can be used to attributing the relative contributions of different 367 aerosol sources [e.g. 26, 79].

369 In order to have reliable data which can also be compared from one site to another, 370 instruments need to be calibrated often enough in the laboratory. This should be 371 conducted within specific calibration centers. In order to assure the data quality, open 372 data flows and joint data analysis are preferable, which will lead to joint publications 373 and provides novel avenues to exploit the data to improve both regional air quality 374 and global climate.

\section{Capacity building}

377

378

379 instruments and stations are necessary pre-requisites for obtaining good data. For 380 example, a proper use of instruments will optimize the efforts, improve the data 381 quality and enhance data and publication flows. 
383 The new insights gained on the secondary aerosol formation and atmospheric 384 phenomena associated with air quality as a whole need to be disseminated from the 385 academia to the public and to the private sector. The academic experts need to keep 386 their knowledge and skills up-to-date and widen their knowledge base with horizontal 387 learning of the adjunct fields in science and technology. Atmospheric research 388 involves several fields of science, such as chemistry, physics, meteorology and Earth 389 system sciences, so deepening and widening the expertise is required. The horizontal 390 learning principle has been shown to be a good example of collaborative problem 391 solving and participatory action research [80]. The shift from discipline-tied 392 fundamental education towards a multi-disciplinarity is imperative for a successful 393 career in climate and global change science [81].

In capacity building, we actually need to answer several questions: What are the target 396 groups? What knowledge needs to be transferred and what are the skills that each 397 target group needs? Concerning the comprehensive atmosphere earth system 398 measurements: Which kind of observation infrastructures is best to improve the air 399 quality in China? Concerning the effective knowledge transfer and innovative 400 thinking methods: What kind of knowledge transfer is needed for sustainable air 401 quality solutions?

402

403 Solution-oriented thinking, need for updating skills as well as knowledge of rapidly 404 changing air quality situation, are crucial. Reliable, research-based education that has 
405 a holistic view on the whole big picture of causes and effects and their interactions

406 and feedbacks affecting air quality will support long lasting solutions. Also basic

407 understanding of the processes behind atmospheric phenomena is needed for building

408 a foundation for evaluating new information. Learning lasts a lifetime, which actually

409 is underlined by the fact that the university professors have pointed out that they

410 deepen their knowledge when lecturing to students.

411

412 5. Future Outlook

413

414 Atmospheric new particle formation contributes significantly to local, regional and 415 global aerosol number and $\mathrm{CCN}$ loads [e.g. 6]. Therefore, understanding of this 416 phenomenon is central to solving the secondary air pollution problem as a whole. The 417 following steps are needed in this process:

418 1) to perform long-term continuous, comprehensive observations on aerosol 419 precursors, oxidants, clusters, ions and aerosol particles together with proper 420 metadata and meteorological data. If needed, new Station for Measuring 421 Ecosystem - Atmosphere Relations II (SMEAR II, [82]) -type flagship stations 422 should be established, since they will help understanding the connections between 423 NPF and land surface - atmosphere interactions and feedbacks,

424 2) to establish calibration centers for mass spectrometers, PSMs and ion $425 \quad$ spectrometers,

426 3) to organize joint data workshops for analyzing atmospheric data in proper, 427 comprehensive manner, 
428 4) to ensure open data and metadata fluxes to other users, and

429 5) to organize joint paper writing workshops and publish the joint papers in peer-

$430 \quad$ reviewed journals.

431 It would be a big step forward to establish tight connections between different 432 Chinese research groups and support further deep collaborations in the future. The 433 second challenge is to establish open data policy and knowledge transfer at all levels.

434 The access to data is crucial to be able to answer research questions and to solve air 435 pollution problem(s). As a good sign, during the last years we have already seen 436 improvements regarding these issues. The third point is the capacity building, 437 including new infrastructures, data flows, databases etc. Furthermore, a new 438 generation of scientists needs to be educated to improve the knowledge base and 439 optimal use of infrastructures and data [86].

440

441 Understanding the formation of secondary pollutants is extremely important, since it 442 enables deep understanding of air pollutant dynamics crucial to air quality. 443 Improving air quality in China has several co-benefits, as it will lead to reduced 444 greenhouse-gas and black carbon emissions and concentrations, together with 445 improved fresh water quality and food supply. The cleaner air will decrease adverse 446 health effects caused by pollutants significantly [83, 84]. Efforts to prevent adverse 447 health effects must be well planned and should occur on multiple levels and places 448 simultaneously. Successful efforts will lead to significant gains in population health, 449 personal well-being and environmental quality as well as improving economy in 450 personal, local and national levels together with other significant co-benefits [85]. 
1

2

3

4

5

8

451 Reducing the use of fossil fuels does not only reduce emissions of air pollutants, but 452 also $\mathrm{CO}_{2}$ and black carbon (BC), thereby decreasing radiative forcing in national and 453 global scales. Also, agricultural production and ecosystem services will benefit from 454 lowered pollutant levels. Healthier food will further improve peoples' health, and less 455 pollution damage improves yields of vegetables and crops. Better insulation of 456 buildings will lower the need for indoor heating, thus reducing emissions, but can also 457 reduce outdoor-indoor penetration of air pollutants. New technology in industry, 458 traffic and energy production will decrease emissions. The reduced pollution will 459 increase solar radiation in ground level and increase potential for solar energy.

460

461 Thus, tackling the air quality rapidly can lead to significant improvement on the 462 quality of life of the population as a whole and can lead to a positive feedback cycle, 463 which will encourage further progress towards cleaner environment.

464

465

466

\section{References}

1. IPCC. 2013. Climate Change 2013: The Physical Science Basis. Stocker T F, Qin D, Plattner G K, Tignor M, Allen S K, Boschung J, Nauels A, Xia Y, Bex V, Midgley P M, eds. Cambridge University Press, Cambridge, United Kingdom and New York, NY, USA, 1535 pp, doi:10.1017/CBO9781107415324 
2. Hand J L, Malm W C. Review of aerosol mass scattering efficiencies from ground-based measurements since 1990. 2007. Journal of Geophysical Research, 112: D16203. doi:10.2029/2007JD008484

3. Lelieveld J, Evans J S, Fnais M, Giannadaki D, Pozzer A. The contribution of outdoor pollution sources to premature mortality on a global scale. 2015 . Nature, 535: 367-371

4. Kulmala M, Nieminen T, Nikandrova A, Lehtipalo K, Manninen H E, Kajos M K, Kolari P, Lauri A, Petäjä T, Krejci R, Hansson H-C, Swietlicki E, Lindroth A, Christensen T R, Arneth A, Hari P, Bäck J, Vesala T, Kerminen V-M. $\mathrm{CO}_{2}$-induced terrestrial climate feedback mechanism: From carbon sink to aerosol source and back. 2014a. Boreal Environmental Research, 19: suppl. B, 122-131

5. Kulmala M, Petäjä T, Ehn M, Thornton J, Sipilä M, Worsnop D R, Kerminen V-M. Chemistry of atmospheric nucleation: On the recent advances on precursor characterization and atmospheric cluster composition in connection with atmospheric new particle formation. 2014b. Annual Review of Physical Chemistry, 65: 21-37

6. Kerminen V-M, Paramonov M, Anttila T, Riipinen I, Fountoukis C, Korhonen H, Asmi E, Laakso L, Lihavainen H, Swietlicki E, Svenningsson B, Asmi A, Pandis S N, Kulmala M, Petäjä T. Cloud condensation nuclei production associated with atmospheric nucleation: a synthesis based on existing literature and new results. 2012. Atmospheric Chemistry and Physics, 12: 12037-12059 
7. Kulmala M, Kerminen V-M. On the formation and growth of atmospheric nanoparticles. 2008. Atmospheric Research, 90: 132-150

8. Zhang R, Khalizov A, Wang L, Hu M, Xu W. Nucleation and growth of nanoparticles in the atmosphere. 2012. Chemical Reviews, 112: 1957-2011

9. Weber R J, Marti J J, McMurry P H, Eisele F L, Tanner D J, Jefferson. Measured atmospheric new particle formation rates: Implications for nucleation mechanisms. 1996. Chemical Engineering Communication, 151: $53-64$

10. Kulmala M, Lehtinen K E J, Laaksonen A. Cluster activation theory as an explanation of the linear dependence between formation rate of $3 \mathrm{~nm}$ particles and sulphuric acid concentration. 2006. Atmospheric Chemistry and Physics, 6: 787-793. doi:10.5194/acp-6-787-2006

11. Kulmala M, Toivonen A, Mäkelä J, Laaksonen A. Analysis of the growth of nucleation mode particles observed in Boreal forest. 1998. Tellus B, 50: 449462

12. Almeida J, Schobesberger S, Kurten A, Ortega I K, Kupiainen-Määttä O, Praplan A P, Adamov A, Amorim A, Bianchi F, Breitenlechner M, David A, Dommen J, Donahue N M, Downard A, Dunne E, Duplissy J, Ehrhart S, Flagan R C, Franchin A, Guida R, Hakala J, Hansel A, Heinritzi M, Henschel H, Jokinen T, Junninen H, Kajos M, Kangasluoma J, Keskinen H, Kupc A, Kurten T, Kvashin A N, Laaksonen A, Lehtipalo K, Leiminger M, Leppä J, Loukonen V, Makhmutov V, Mathot S, McGrath M J, Nieminen T, Olenius T, Onnela A, Petäjä T, Riccobono F, Riipinen I, Rissanen M, Rondo L, 24 
Ruuskanen T, Santos F D, Sarnela N, Schallhart S, Schnitzhofer R, Seinfeld J H, Simon M, Sipilä M, Stozhkov Y, Stratmann F, Tome A, Tröstl J, Tsagkogeorgas G, Vaattovaara P, Viisanen Y, Virtanen A, Vrtala A, Wagner P E, Weingartner E, Wex H, Williamson C, Wimmer D, Ye P L, Yli-Juuti T, Carslaw K S, Kulmala M, Curtius J, Baltensperger U, Worsnop D R, Vehkamäki H, Kirkby J. Molecular understanding of sulphuric acid-amine particle nucleation in the atmosphere. Nature, 2013, 502: 359-363

13. Ehn M, Thornton J A, Kleist E, Sipilä M, Junninen H, Pullinen I, Springer M, Rubach F, Tillmann R, Lee B, Lopez-Hifiker F, Andres S, Acir I H, Rissanen M, Jokinen T, Schobesberger S, Kangasluoma J, Kontkanen J, Nieminen T, Kurten T, Nielsen L B, Jorgensen S, Jaergaard H G, Canagaratna M, Dal Maso M, Berndt T, Petäjä T, Wahner A, Kerminen V-M, Kulmala M, Worsnop D, Wildt J, Mentel T F. A large source of low-volatility secondary organic aerosol. 2014. Nature, 506: 476-479

14. Jokinen T, Berndt T, Makkonen R, Kerminen V-M, Junninen H, Paasonen P, Stratmann F, Herrmann H, Guenther A, Worsnop D R, Kulmala M, Ehn M, Sipilä M. Production of extremely low-volatile organic compounds from biogenic emissions: measured yields and atmospheric implications. 2015. Proceedings of the National Academy of Sciences of the United States of America, 112: 7123-7128

15. McMurry P H, Friedlander S K. New particle formation in the presence of aerosol. 1979. Atmospheric Environment, 13: 1635-1651 
16. Kerminen V-M, Pirjola L, Kulmala M. How significantly does coagulational scavenging limit atmospheric particle production? 2001. Journal of Geophysical Research, 106: 24119-24126

17. Lehtinen K E J, Dal Maso M, Kulmala M, Kerminen V-M. Estimating nucleation rates from apparent particle formation rates and vice-versa: Revised formulation of the Kerminen-Kulmala equation. 2007. Journal of Aerosol Science, 38: 988-994

18. Kulmala M, Kontkanen J, Junninen H, Lehtipalo K, Manninen H E, Nieminen T, Petäjä T, Sipilä M, Schobesberger S, Rantala P, Franchin A, Jokinen T, Järvinen E, Äijälä M, Kangasluoma J, Hakala J, Aalto P P, Paasonen P, Mikkilä J, Vanhanen J, Aalto J, Hakola H, Makkonen U, Ruuskanen T, Mauldin III R L, Duplissy J, Vehkamäki H, Bäck J, Kortelainen A, Riipinen I, Kurten T, Johnston M V, Smith J N, Ehn M, Mentel T F, Lehtinen K E J, Laaksonen A, Kerminen V-M, Worsnop D R. Direct observations of atmospheric aerosol nucleation. 2013. Science, 339: 943-946

19. Vehkamäki H, Riipinen I. Thermodynamics and kinetics of atmospheric aerosol particle formation and growth. 2012. Chemistry Society Review, 41

20. Buonanno G, Marks G B, Morawska L. Health effects of daily airborne particle dose in children: Direct association between personal dose and respiratory health effects. Environmental Pollution, 2013, 180: 246-250

21. Kulmala M, Kerminen V-M, Anttila T, Laaksonen A, O’Dowd C D. Organic aerosol formation via sulphate cluster activation. 2004. Journal of Geophysical Research, 109 (D4). doi: 10.1029/2003JD003961 
563 22. Rosenfeld D, Sherwood S, Wood R, Donner L. Climate effects of aerosol-

$564 \quad$ cloud interactions. 2014. Science, 343: 379-380

565 23. Qu W J, Wang J, Zhang X Y, Wang D, Sheng L F. Influence of relative 566 humidity on aerosol composition: Impacts on light extinction and visibility 567 impairment at two sites in coastal area of China. 2015. Atmospheric Research, $568 \quad 153: 500-511$

569 24. Nemmar A, Hoet P H, Vanquickenborne B, Dinsdate D, Thomeer M, 570 Hoylaerts M F, Valbilloen H, Mortelmans L, Nemery B. Passage of inhaled 571 particles into the blood circulation in humans. 2002. Circulation, 105: 411-414 572 25. Guo S, Hua M, Zamorab M L, Peng J F, Shang D J, Zheng J, Du Z F, Wu Z J, 573 Shao M, Zeng L M, Molinac M J, Zhang R Y. Elucidating severe urban haze 574 formation in China. 2014. Proceedings of the National Academy of Sciences $575 \quad$ of the United States of America, 111: 17373-17378

26. Huang R J, Zhang Y L, Bozzetti C, Ho K F, Cao J J, Han Y M, Daellenbach K R, Slowik J G, Platt S M, Canonaco F, Zotter P, Wolf R, Pieber S M, Bruns E A, Crippa M, Ciarelli G, Piazzalunga A, Schwikowski M, Abbaszade G, Schnelle-Kreis J, Zimmermann R, An Z, Szidat S, Baltensperger U, El Haddad I, Prévôt A S H. High secondary aerosol contribution to particulate pollution during haze events in China. 2014. Nature 514: $218-222$

27. Wu Z J, Hu M, Liu S, Wehner B, Bauer S, Ma Bling A, Wiedensohler A, 584 Petäjä T, Dal Maso M, Kulmala M. New particle formation in Beijing, China: 
Statistical analysis of a 1-year data set. 2007. Journal of Geophysical Research: Atmospheres, 112: D09209. doi 10.1029/2006jd007406

30. Xie Y, Ding A, Nie W, Mao H, Qi X, Huang X, Xu Z, Kerminen V-M, Petäjä T, Chi X, Virkkula A, Boy M, Xue L, Guo J, Sun J, Yang X, Kulmala M, Fu C. Enhanced sulfate formation by nitrogen dioxide: Implications from in situ observations at the SORPES station. 2015. Journal of Geophysical Research: Atmospheres, 120, 24: 12679-12694

\section{Kulmala M. China’s choking cocktail. 2015. Nature, 526: 497-499}

32. Fiore A M, Naik V, Spracklen D V, Steiner A, Unger N, Prather M, Bergmann D, Cameron-Smith P J, Cionni I, Collins W J, Dalsoren S, Eyring V, Folberth G A, Ginoux P, Horowitz L W, Josse B, Lamarque J F, MacKenzie I A, Nagashima T, O'Connor F M, Righi M, Rumbold S T, Shindell D T, Skeie R B, Sudo K, Szopa S, Takemura T, Zeng G. Global air quality and climate. 2012. Chemical Society Reviewes, 41: 6663-6683. doi:10.1039/c2cs35095e 

607 33. Fuzzi S, Baltensperger U, Carslaw K, Decesari S, Denier van der Gon H, 608 Facchini M C, Fowler D, Koren I, Langford B, Lohmann U, Nemitz E, Pandis 609 S, Riipinen I, Rudich Y, Schaap M, Slowik J G, Spracklen D V, Vignati E, 610 Wild M, Williams M, Gilardoni S. Particulate matter, air quality and climate: 611 lessons learned and future needs. 2015. Atmospheric Chemistry and Physics, $612 \quad 15: 8217-8299$

613 34. Hari P, Petäjä T, Bäck J, Kerminen V-M, Lappalainen H K, Vihma T, Laurila 614 T, Viisanen Y, Vesala T, Kulmala M. Conceptual design of a measurement 615 network of the global change. 2016. Atmospheric Chemistry and Physics, 16: $616 \quad 1017-1028$

617 35. Ding A, Fu C, Yang X, Sun J, Zheng L, Xie Y, Herrmann E, Nie W, Petäjä T, 618 Kerminen V-M, Kulmala M. Ozone and fine particle in the western Yangtze 619 river delta: an overview of $1 \mathrm{yr}$ data at the SORPES station. 2013a. 620 Atmospheric Chemistry and Physics, 13: 5813-5830

621 36. Ding A J, Fu C B, Yang X Q, Sun J N, Petäjä T, Kerminen V-M, Wang T, Xie 622 Y N, Herrmann E, Zheng L F, Nie W, Wei L W, Kulmala M. Intense 623 atmospheric pollution modifies weather: a case of mixed biomass burning with 624 fossil fuel combustion pollution in the eastern China. 2013b. Atmospheric 625 Chemistry and Physics, 13: 10545-10554

626 37. Petäjä T, Järvi L, Kerminen V-M, Ding A, Sun J, Nie W, Kujansuu J, 627 Virkkula A, Yang X, Fu C, Zilitinkevich S, Kulmala M. Air pollution: a new 628 wall of China. 2016. Scientific Reports 
38. Lin $\mathrm{P}, \mathrm{Hu} \mathrm{M}, \mathrm{Wu} \mathrm{Z}$, Niu Y, Zhu T. Marine aerosol size distributions in the springtime over China adjacent seas. 2007 Atmospheric Environment, 41: 6784-6796, doi10.1016/j.atmosenv.2007.04.045

39. Liu S, Hu M, Wu Z J, Wehner B, Wiedensohler A, Cheng Y F. Aerosol number size distribution and new particle formation at a rural/coastal site in Pearl River Delta (PRD) of China. 2008. Atmospheric Environment, 42: 62756283, doi10.1016/j.atmosenv.2008.01.063

40. Gong Y G, Hu M, Cheng Y, Su H, Yue D, Liu F, Wiedensohler A, Wang Z, Kalesse H, Liu S, Wu Z, Xiao K, Mi P, Zhang Y. Competition of coagulation sink and source rate: New particle formation in the Pearl River Delta of China. 2010. Atmospheric Environment, 44: 3278-3285. doi: 10.1016/j.atmosenv.2010.05.049

41. Yue D L, Hu M, Zhang R Y, Wang Z B, Zheng J, Wu Z J, Wiedensohler A, He L Y, Huang X F, Zhu T. The roles of sulfuric acid in new particle formation and growth in the mega-city of Beijing. 2010. Atmospheric Chemistry and Physics, 10: 4953-4960

42. Wu Z J, Hu M, Yue D L, Liu S, Wehner B, Wiedensohler A. Evolution of particle number size distribution in an urban atmosphere during episodes of heavy pollution and new particle formation. 2011. Science China Earth Science, 54: 1772-1778

43. Yue D L, Hu M, Zhang R Y, Wu Z J, Su H, Wang Z B, Peng J F, He L Y, Huang X F, Gong Y G, Wiedensohler A. Potential contribution of new particle 


651 formation to cloud condensation nuclei in Beijing. 2011. Atmospheric
652 Environment, 45: 6070-6077
653 44. Wang Z B, Hu M, Mogensen D, Yue D L, Zheng J, Zhang R Y, Liu Y, Yuan
654 B, Li X, Shao M, Zhou L, Wu Z J, Wiedensohler A, Boy M. The simulations
655 of sulfuric acid concentration and new particle formation in an urban
656 atmosphere in China. 2013a. Atmospheric Chemistry and Physics, 13: 11157-
$657 \quad$ 11167. 10.5194/acp-13-11157-2013

658 45. Yue D L, Hu M, Wang Z B, Wen M T, Guo S, Zhong L J, Wiedensohler A, 659 Zhang Y H. Comparison of particle number size distributions and new 660 particle formation between the urban and rural sites in the PRD region, China. 661 2013. Atmospheric Environment, 76: 181-188

662 46. Peng J F, Hu M, Wang Z B, Huang X F, Kumar P, Wu Z J, Guo S, Yue D L, 663 Shang D J, Zheng Z, He L Y. Submicron aerosols at thirteen diversified sites 664 in China: size distribution, new particle formation and corresponding 665 contribution to cloud condensation nuclei production. 2014. Atmospheric 666 Chemistry and Physics, 14: 10249-10265, 10.5194/acp-14-10249-2014

667 47. Qi X, Ding A J, Nie W, Petäjä T, Kerminen V-M, Herrmann E, Xie Y N, 668 Zheng L F, Manninen H, Aalto P, Sun J N, Xu Z N, Chi X G, Huang X, Boy 669 M, Virkkula A, Yang X Q, Fu C B, Kulmala M. Aerosol size distribution and 670 new particle formation in western Yangtze River Delta of China: two-year 671 measurement at the SORPES station. 2015. Atmospheric Chemistry and 672 Physics Discussions, 15: 12491-12537 
48. Wehner B, Wiedensohler A, Tuch T M, Wu Z J, Hu M, Slanina J, Kiang C S. Variability of the aerosol number size distribution in Beijing, China: New particle formation, dust storms, and high continental background. 2004. Geophysical Research Letters, 31: L22108

49. Wang Z B, Hu M, Wu Z J, Yue D L, He L Y, Huang X F, Liu X G, Wiedensohler A. Long-term measurements of particle number size 


\begin{abstract}
696 54. Kulmala M, Dal Maso M, Mäkelä J M, Pirjola L, Väkevä M, Aalto P, 697 Miikkulainen P, Hämeri K, O'Dowd C D. On the formation, growth and 698 composition of nucleation mode particles. 2001. Tellus, 53B: 479-480

699 55. Kulmala M, Petäjä T, Mönkkönen P, Koponen I K, Dal Maso M, Aalto P P, 700 Lehtinen K E J, Kerminen V-M. On the growth of nucleation mode particles: 701 source rates of condensable vapor in polluted and clean environments. 2005. $702 \quad$ Atmospheric Chemistry and Physics, 5: 409-416

703 56. Wang Z B, Hu M, Sun J Y, Wu Z J, Yue D L, Shen X J, Zhang Y M, Pei X Y, 704 Cheng Y F, Wiedensohler A. Characteristics of regional new particle 705 formation in urban and regional background environments in the North China 706 Plain. 2013b. Atmospheric Chemistry and Physics, 13: 12495-12506. $707 \quad 10.5194 / \mathrm{acp}-13-12495-2013$
\end{abstract}

708 57. Wang Z B, Hu M, Yue D L, He L Y, Huang X F, Yang Q, Zheng J, Zhang R 709 Y, Zhang Y H. New particle formation in the presence of a strong biomass 710 burning episode at a downwind rural site in PRD, China. 2013e. Tellus B, 65:

58. Dupart Y, King S M, Nekat B, Nowak A, Wiedensohler A, Herrmann H, 713 David G, Thomas B, Miffre A, Rairoux P, D’Anna B, George C. Mineral dust 714 photochemistry induces nucleation events in the presence of SO2. 2012. 715 Proceedings of the National Academy of Sciences, 109: 20842-20847. doi: $716 \quad 10.1073 /$ pnas. 1212297109

717 59. Nie W, Ding A J, Xie Y N, Xu Z, Mao H, Kerminen V M, Zheng L F, Qi X 718 M, Huang X, Yang X Q, Sun J N, Herrmann E, Petäjä T, Kulmala M, Fu C B. 33 
Influence of biomass burning plumes on HONO chemistry in eastern China. 2015. Atmospheric Chemistry and Physics, 15: 1147-1159

60. He H, Wang Y, Ma Q, Ma J, Chu B, Ji D, Tang G, Liu C, Zhang H, Hao J. Mineral dust and NOx promote the conversion of SO2 to sulfate in heavy pollution days. 2014. Scientific Reports, 4: 4172

61. Vanhanen J, Mikkilä J, Lehtipalo K, Sipilä M, Manninen H E, Siivola E, Petäjä T, Kulmala M. Particle size magnifier for nano-CN Detection. 2011. Aerosol Science and Technology, 45: 533-542

62. Kulmala M, Riipinen I, Sipilä M, Manninen H E, Petäjä T, Junninen H, Dal Maso M, Mordas G, Mirme A, Vana M, Hirsikko A, Laakso L, Harrison R M, Hanson I, Leung C, Lehtinen K E J, Kerminen V-M. Towards direct measurement of atmospheric nucleation. 2007. Science, 318: 89-92

63. Tammet H. Symmetric Inclined Grid Mobility Analyzer for the Measurement of Charged Clusters and Fine Nanoparticles in Atmospheric Air. 2011. Aerosol Science and Technology, 45: 468-479

64. Kulmala M, Petäjä T, Nieminen T, Sipilä M, Manninen H E, Lehtipalo K, Dal Maso M, Aalto P P, Junninen H, Paasonen P, Riipinen I, Lehtinen K E J, Laaksonen A, Kerminen V-M. Measurement of the nucleation of atmospheric aerosol particles. 2012. Nature Protocols, 7: 1651-1667

65. Lehtipalo K, Leppä J, Kontkanen J, Kangasluoma J, Franchin A, Wimmer D, Schobesberger S, Junninen H, Petäjä T, Sipilä M, Mikkilä J, Vanhanen J, Worsnop D R, Kulmala M. Methods for determining particle size distribution 
and growth rates between 1 and $3 \mathrm{~nm}$ using the Particle Size Magnifier. 2014. Boreal Environmental Research, 19: B, 215-236

66. Gagné S, Nieminen T, Kurtén T, Manninen H E, Petäjä T, Laakso L, Kerminen V-M, Boy M, Kulmala M. Factors influencing the contribution of ion-induced nucleation in a boreal forest, Finland. 2010. Atmospheric Chemistry and Physics, 10: 3743-3757

67. Kulmala M, Riipinen I, Nieminen T, Hulkkonen M, Sogacheva L, Manninen H E, Paasonen P, Petäjä T, Dal Maso M, Aalto P P, Viljanen A, Usoskin I, Vainio R, Mirme S, Mirme A, Minikin A, Petzold A, Härrak U, Plaß-Dülmer C, Birmili, Kerminen V-M. Atmospheric data over a solar cycle: no connection between galactic cosmic rays and new particle formation. 2010 . Atmospheric Chemistry and Physics, 10: 1885-1898

68. Junninen H, Ehn M, Petäjä T, Luosujärvi L, Kotiaho T, Kostiainen R, Rohner U, Gonin M, Fuhrer K, Kulmala M, Worsnop D R. A high-resolution mass spectrometer to measure atmospheric ion composition. 2010. Atmospheric Measurement Techniques, 3: 1039-1053. doi:10.5194/amt-3-1039-2010

69. Jokinen T, Sipilä M, Junninen H, Ehn M, Lönn G, Hakala J, Petäjä T, Mauldin III R L, Kulmala M, Worsnop D R. Atmospheric sulfuric acid and neutral cluster measurements using CI-Api-TOF. 2012. Atmospheric Chemistry and Physics, 12: 4117-4125

70. Petäjä T, Mauldin III R L, Kosciuch E, McGrath J, Nieminen T, Paasonen P, Boy M, Adamov A, Kotiaho T, Kulmala M. Sulfuric acid and $\mathrm{OH}$ 
concentrations in a boreal forest site. 2009. Atmospheric Chemistry and Physics, 9: 7435-7448

71. Sipilä, M, Berndt T, Petäjä T, Brus D, Vanhanen J, Stratmann F, Patokoski J, Mauldin III R L, Hyvärinen A P, Lihavainen H, Kulmala M. The role of sulfuric acid in atmospheric nucleation. 2010. Science, 327: 1243-1246

72. Kirkby J, Curtius J, Almeida J, Dunne E, Duplissy J, Ehrhart S, Franchin A, Gagné S, Ickes L, Kürten A, Kupc A, Metzger A, Riccobono F, Rondo L, Schobesberger S, Tsagkogeorgas G, Wimmer D, Amorim A, Bianchi F, Breitenlechner M, David A, Dommen J, Downard A, Ehn M, Flagan R C, Haider S, Hansel A, Hauser D, Jud W, Junninen H, Kreissl F, Kvashin A, Laaksonen A, Lehtipalo K, Lima J, Lovejoy E R, Makhmutov V, Mathot S, Mikkilä J, Minginette P, Mogo S, Nieminen T, Onnela A, Pereira P, Petäjä T, Schnitzhofer R, Seinfeld J H, Sipilä M, Stozhkov Y, Stratmann F, Tomé A, Vanhanen J, Viisanen Y, Vrtala A, Wagner P E, Walther H, Weingartner E, Wex H, Winkler P M, Carslaw K S, Worsnop D R, Baltensperger U, Kulmala M. The role of sulfuric acid, ammonia and galactic cosmic rays in atmospheric aerosol nucleation. 2011. Nature, 476: 429-433

73. Petäjä T, Sipilä M, Paasonen P, Nieminen T, Kurtén T, Ortega I K, Stratmann F, Vehkamäki H, Berndt T, Kulmala M. Experimental observation of strongly bound dimers of sulphuric acid: application to nucleation in the atmosphere. 2011. Physical Review Letters, 106: 228302

74. Riccobono F, Schobesberger S, Scott C E, Dommen J, Ortega I K, Rondo L, Almeida J, Amorim A, Bianchi F, Breitenlechner M, David A, Downard A, 
Dunne E M, Duplissy J, Ehrhart S, Flagan R C, Franchin A, Hansel A, Junninen H, Kajos M, Keskinen H, Kupc A, Kürten A, Kvashin A N, Laaksonen A, Lehtipalo K, Makhmutov V, Mathot S, Nieminen T, Onnela A, Petäjä T, Praplan AP, Santos F D, Schallhart S, Seinfeld J H, Sipilä M, Spracklen D V, Stozhkov Y, Stratmann F, Tomé A, Tsagkogeorgas G, Vaattovaara P, Viisanen Y, Vrtala A, Wagner P E, Weingartner E, Wex H, Wimmer D, Carslaw K S, Curtius J, Donahue N M, Kirkby J, Kulmala M, Worsnop D R, Baltensperger U. Oxidation products of biogenic emissions contribute to nucleation of atmospheric particles. 2014. Science, 344: 717-721

75. Mauldin III R L, Berndt T, Sipilä M, Paasonen P, Petäjä T, Kim S, Kurtén T, Stratmann F, Kerminen V-M, Kulmala M. New atmospherically relevant oxidant. 2012. Nature, 488: 193-197

76. Taipale R, Sarnela N, Rissanen M, Junninen H, Rantala P, Korhonen F, Siivola E, Berndt T, Kulmala M, Mauldin III R L, Petäjä T, Sipilä M. New instrument for measuring atmospheric concetrations of non- $\mathrm{OH}$ oxidants of SO2. 2014. Boreal Environment Research, 19: B, 55-70

77. Mauldin III R L, Rissanen M P, Petäjä T, Kulmala M. Furthering information from $\mathrm{OH}$ and $\mathrm{HO} 2+\mathrm{RO} 2$ observations using a high resolution time of flight mass spectrometer. 2016. Atmospheric Measurement Techniques Discussions, doi:10.5194/amt-2015-398

78. Wiedensohler A, Birmili W, Nowak A, Sonntag A, Weinhold K, Merkel M, Wehner B, Tuch T, Pfeifer S, Fiebig M, Fjaraa A M, Asmi E, Sellegri K, Depuy R, Venzac H, Villani P, Laj P, Aalto P, Ogren J A, Swietlicki E, 


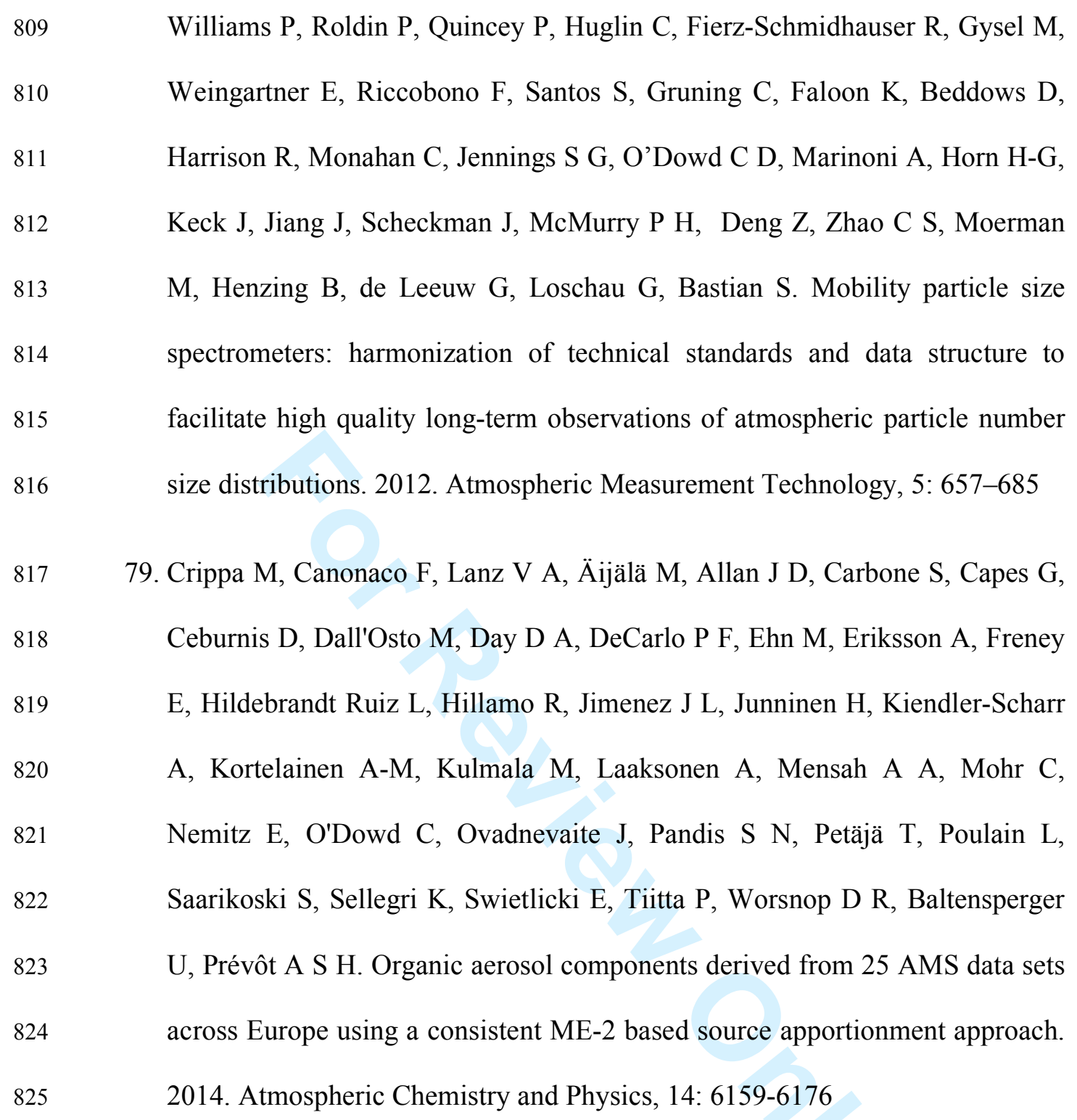

Williams P, Roldin P, Quincey P, Huglin C, Fierz-Schmidhauser R, Gysel M, Weingartner E, Riccobono F, Santos S, Gruning C, Faloon K, Beddows D, Harrison R, Monahan C, Jennings S G, O’Dowd C D, Marinoni A, Horn H-G, Keck J, Jiang J, Scheckman J, McMurry P H, Deng Z, Zhao C S, Moerman M, Henzing B, de Leeuw G, Loschau G, Bastian S. Mobility particle size spectrometers: harmonization of technical standards and data structure to facilitate high quality long-term observations of atmospheric particle number size distributions. 2012. Atmospheric Measurement Technology, 5: 657-685

79. Crippa M, Canonaco F, Lanz V A, Äijälä M, Allan J D, Carbone S, Capes G, Ceburnis D, Dall'Osto M, Day D A, DeCarlo P F, Ehn M, Eriksson A, Freney E, Hildebrandt Ruiz L, Hillamo R, Jimenez J L, Junninen H, Kiendler-Scharr A, Kortelainen A-M, Kulmala M, Laaksonen A, Mensah A A, Mohr C, Nemitz E, O'Dowd C, Ovadnevaite J, Pandis S N, Petäjä T, Poulain L, Saarikoski S, Sellegri K, Swietlicki E, Tiitta P, Worsnop D R, Baltensperger U, Prévôt A S H. Organic aerosol components derived from 25 AMS data sets across Europe using a consistent ME-2 based source apportionment approach. 2014. Atmospheric Chemistry and Physics, 14: 6159-6176

80. Hennessy S, Murphy P. The Potential for Collaborative Problem Solving in Design and Technology. 1999. International Journal of Technology and Design Education 9: 1, 1-36

81. Nordic Climate Change Research. 2009: NordForsk Policy Briefs 2009-8. Mandag Morgen, 2009 
831 82. Hari P, Kulmala M. Station for Measuring Ecosystem - Atmosphere Relations (SMEAR II). 2005. Boreal Environment Research, 10: 315-322

83. Zhang J, Mauzerall D L, Zhu T, Liang S, Ezzati M, Remais J V. Environmental health in China: progress towards clean air and safe water. 2010. Lancet, 375: 9720

84. Tang D, Wang C, Nie J, Chen R, Niu Q, Kan H, Chen B, Perera F. Health benefits of improving air quality in Taiyuan, China. 2014. Environment International, 73: 235-242. http://dx.doi.org/10.1016/j.envint.2014.07.016

85. Haines A, McMichael A J, Smith K R, Roberts I, Woodcock J, Markandya A, Armstrong B G, Campbell-Lendrum D, Dangour A D, Davies M, Bruce N, Tonne C, Barrett M, Wilkinson P. Public health benefits of strategies to reduce greenhouse-gas emissions: overview and implications for policy makers. 2009. Lancet, 374: 2104

86. Lappalainen H K, Kerminen V M, Petäjä T, Kurten T, Baklanov A, Shvidenko A, Bäck J, Vihma T, Alekseychik P, Arnold S, Arshinov M, Asmi E, Belan B, Bobylev L, Chalov S, Cheng Y, Chubarova N, de Leeuw G, Ding A, Dobrolyubov S, Dubtsov S, Dyukarev E, Elansky N, Eleftheriadis K, Esau I, Filatov N, Flint M, Fu C, Glezer O, Gliko A, Heimann M, Holtslag A M, Hõrrak U, Janhunen J, Juhola S, Järvi L, Järvinen $H$, Kanukhina A, Konstantinov P, Kotlyakov V, Kieloaho A-J, Komarov A, Kujansuu J, Kukkonen I, Kyrö E, Laaksonen A, Laurila T, Lihavainen H, Lisitzin A, Mahura A, Makshtas A, Mareev E, Mazon S, Matishov D, Melnikov V, Mikhailov E, Moisseev D, Nigmatulin R, Noe S M, Ojala A, Pihlatie M, 
Popovicheva O, Pumpanen J, Regerand T, Repina I, Shcherbinin A,

855

856

857

858

859

860

861

862

863

\section{Acknowledgements}

865 The work in this manuscript is supported by Academy of Finland via Center of 866 Excellence in Atmospheric Sciences (project no. 272041) and the Finnish Funding 867 Agency for Technology and Innovation TEKES via Beautiful Beijing project 868 (3667/31/2013) and European Research Council Advanced Grant (ATMNUCLE, 869 227463) and InGOS DEFROST and CRAICC (no 26060) and Nordforsk CRAICC870 PEEX (amendment to contact 26060) funded by Nordforsk. The SORPES station was 871 supported by Nanjing University and the Collaborative Innovation Center of Climate 872 Change in Jiangsu Province, China. Part of Aijun Ding's work was supported by the 873 excellent young scientist fund of National Natural Science Foundation of China 874 (D0512/ 41422504).

875 876
Shevchenko V, Sipilä M, Skorokhod A, Spracklen D V, Su H, Subetto D, Sun

J, Terzhevik A, Timofeyev Y, Troitskaya Y, Tynkkynen V-P, Kharuk V I, Zaytseva N, Zhang J, Viisanen Y, Vesala T, Hari P, Hansson H-C, Matvienko

G, Kasimov N, Guo H, Bondur V, Zilitinkevich S, Kulmala M. Pan-Eurasian Experiment (PEEX): Towards holistic understanding of the feedbacks and interactions in the land - atmosphere - ocean- society continuum in the Northern Eurasian region. 2016. Atmospheric Chemistry and Physics - PEEX Special Issue, submitted 
Research highlights

1) Formation of new atmospheric aerosol particles is a global phenomenon that has been observed to take place in even heavily-polluted environments. A holistic scientific understanding on the atmospheric phenomena associated with air quality as a whole, as well as on the connection between air quality and climate, is lacking at the moment.

2) In China, new particle production has been observed at very high pollution levels (condensation sink about $0.1 \mathrm{~s}^{-1}$ ) in several megacities. With a network of observation stations, we will be able to understand the interactions and feedbacks associated with the urban pollution mixture, and ultimately, be ready to make targeted strategies for the pollution control.

3) This paper summaries the recent advances in studying secondary new aerosol formation in China to show how increased process-level understanding will help us to understand air quality-climateweather interactions and how the feedbacks and interactions affect the air quality in highly-polluted environments such as those frequently encountered in Chinese megacities. 


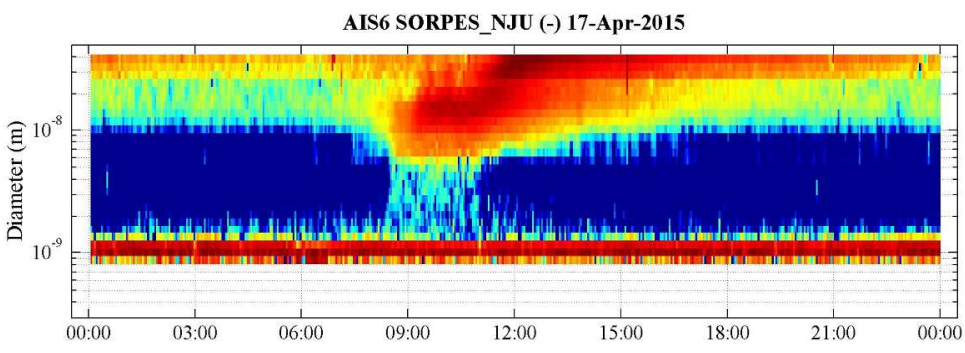

AIS6 SORPES_NJU (+) 17-Apr-2015

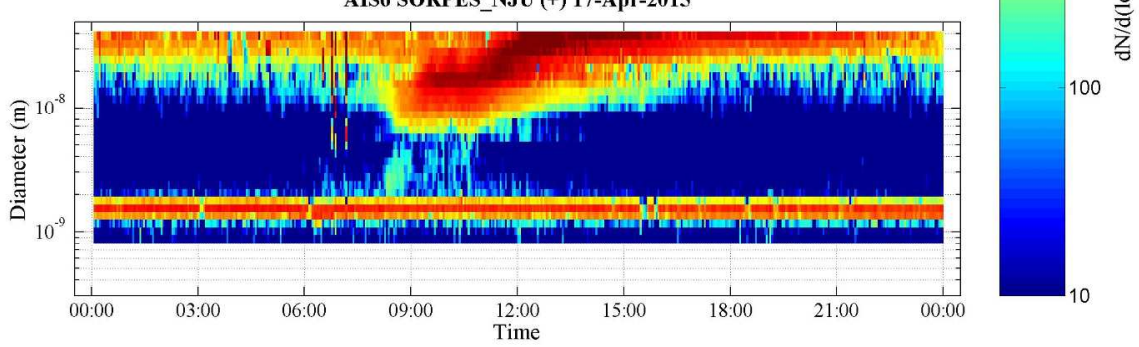

Figure 1. A typical nucleation event measured using Air Ion Spectrometer (AIS) at the SORPES station, Nanjing, in China. The background cluster ions are seen in both negative and positive ion modes in the sub$2 \mathrm{~nm}$ size range. Negative ion clusters are smaller than positive ones. The new particle formation is seen in both polarities starting at around $8.30 \mathrm{am}$. Here 36 is $1.8 \mathrm{~cm}-3 \mathrm{~s}-1$ and $\mathrm{GR}(6-30 \mathrm{~nm})$ is $6.6 \mathrm{~nm} / \mathrm{hr}$.

$871 \times 523 \mathrm{~mm}(72 \times 72 \mathrm{DPI})$ 